\title{
ASSESSMENT OF METALLIC MOBILE FRACTION BIOAVAILABLE FROM DIFFERENT SEWAGE SLUDGE SAMPLES USING LEACHING TEST
}

\author{
$\underline{\text { Nicoleta Mirela Marin }}{ }^{1,2}$, Marius Simion ${ }^{1}$, Luoana Florentina Pascu ${ }^{1}$ \\ ${ }^{1}$ National Research and Development Institute for Industrial Ecology, Drumul Podu \\ Dambovitei no 71-73, district 6, Bucharest, Romania \\ ${ }^{2}$ Department of Analytical Chemistry, Faculty of Chemistry, University of Bucharest, 2- \\ 14 Blvd. Regina Elisabeta, 030018, Bucharest, Romania
}

\begin{abstract}
Analysis of metallic mobile fraction from sewage sludge wastewater treatment plants provides very useful information about the possibility of metallic mobile forms to migrate on the environment. Therefore, determination of total metallic mobile fraction, refers not only to exchange fraction but also to bonded metals in sewage sludge structure which can usually be removed with strong extractants. Together with leaching test are provided informations about the bioavailability of toxic metals in normal environmental conditions. In this condition, for assessing the risk of pollution induced by metals it is necessary to evaluate both, total and mobile content available for environment. In this paper a leached extraction method according to SR EN ISO 12457:2003 standard, that uses an extraction procedure (sludge-solution 1-10 $(\mathrm{m} / \mathrm{v}), 24 \mathrm{~h}, 40 \mathrm{rpm})$ was applied. As, $\mathrm{Cd}$, Co, Cr, Cu, Mo, Ni, Pb, Se and $\mathrm{Zn}$ were detected in extractible solution by ICP-EOS technique. The metals detected after leaching test were compared with the values imposed by the current legislation and function of the results obtained was indicated the possibility to storage the sludge as a non-hazardous waste or the opportunity to use it as a fertilizer in agriculture.
\end{abstract}

Keywords: heavy metals, mobile fraction, sewage sludge, ICP-EOS

\section{Introduction}

Utilization of the activated sludge during the biological step of the wastewater treatment process is one of the major and actual research topics. The management of this biological step becomes a growing issue due to the more restrictive environmental legislation. In this respect, the wastewater treatment process should be coupled to the management and usage of the sludge resulted from the treatment process. Moreover, the usage of the resulted sludge in the agricultural field is an acceptable alternative from the economical and recycling point of view. The urban sludge encompassed some nutritive compounds essential for plant growth. Moreover, it could enhance the soil properties which could be used in agriculture, but only in the situation when the heavy metal concentrations are in between the legal range [1-2]. Height content of heavy metals can cause contamination of ground water, produce an adverse effect for soil biological proprieties, be toxic for plants. Above the admissible level, heavy metals reduce significant soil fertility and they can produce also inhibit enzyme activity in the soil and alter soil acidity. Bases on their toxicity heavy metals are divided in two groups, the first group includes mercury, cadmium and lead, which are highly toxic for humans, animals and less damaging for plants, the second group includes cooper, zinc and nickel which are more damaging for plants than animals, living organisms and human. In sewage sludge, heavy metals can be find in mobile form that migrate from sludge to 
the agricultural soli and also in immobile form that does not produce any toxicological effect under natural environmental conditions [3].

Using a different extraction method, compressive information can be obtained about the origin, mod of occurrence, biological and physicochemical bioavailability, mobilization and transport of heavy metals [4].

The goal of this study was to evaluate the metallic mobile fraction of As, Cd, Co, Cr, $\mathrm{Cu}$, Mo, $\mathrm{Ni}, \mathrm{Pb}$, Se and $\mathrm{Zn}$ bioavailable from different sewage sludge samples in accordance with leaching test.

\section{Materials and Methods}

\section{Samples collection}

The tests were done on municipal sewage sludge collected from Bacau, Satu Mare, Buzau, Botosani (Romania). After sampling the sewage sludge samples (approximately $1 \mathrm{~kg}$ ) were kept at $4^{\circ} \mathrm{C}$ during the transport to the laboratory.

\section{Apparatus}

The analysis of heavy metals from sewage sludge samples was carried out according to SR EN ISO 11885:2009 [5] using a ICP-OES Optima 5300 DV Perkin Elmer Spectrometer, ICP-OES parameters and the wavelength used of the analyses are presented in table 1 and SR EN ISO 17852:2008 [6] using a Mercury Analyzer Tedelyne type Cetac QuickTrace M-8000. Microwave Digestion System Ethos Up Milestone was used for digestion of sewage sludge samples with aqua regia. Determination of heavy metals from each sample was repeated two times.

\section{Reagents and calibration}

All reagents used were of analytical purity, hydrochloric acid $37 \%$, nitric acid $67 \%$ and $100 \mathrm{mg} \cdot \mathrm{L}^{-1} \mathrm{XVI}$ Certipur for ICP were purchased from Merck, Germany. In order to reduce the potential contamination, all glassware were kept in 1:1 $\mathrm{HNO}_{3}$ for one day, subsequently they were washed with $3 \% \mathrm{HNO}_{3}$.

Calibration curves for determination of total mobile concentrations were prepared in the range $0.5-2.5 \mathrm{mg} / \mathrm{L}$ with $100 \mathrm{mg} \cdot \mathrm{L}^{-1} \mathrm{XVI}$ Certipur for ICP in aqua regia and for determination of metallic mobile fraction bioavailable for environment were prepared calibration curves in the range $0.1-0.5 \mathrm{mg} / \mathrm{L}$ with $100 \mathrm{mg} \cdot \mathrm{L}^{-1} \mathrm{XVI}$ Certipur for ICP, Merck quality in nitric acid $3 \%$.

Table 1. The emission wavelengths and the operating parameters used in ICP-OES

\begin{tabular}{|c|c|c|c|}
\hline Metallic elements & $\begin{array}{c}\text { ICP-OES } \\
\text { Wavelength }(\mathbf{n m})\end{array}$ & \multicolumn{2}{|c|}{ ICP-OES Spectrometer parameters } \\
\hline $\mathrm{As}$ & 188.979 & Delay time & $60 \mathrm{~s}$ \\
\hline $\mathrm{Cd}$ & 228.802 & Replicates & 2 times \\
\hline $\mathrm{Cr}$ & 267.716 & \multicolumn{2}{|c|}{ Plasma parameters } \\
\hline $\mathrm{Cu}$ & 327.393 & Plasma flow rate & $15{\mathrm{~L} \cdot \mathrm{min}^{-1}}^{-1}$ \\
\hline $\mathrm{Mo}$ & 202.031 & Auxiliar flow rate & $0.2{\mathrm{~L} \cdot \mathrm{min}^{-1}}^{-1}$ \\
\hline $\mathrm{Ni}$ & 231.604 & Nebulizer flow rate & $0.9{\mathrm{~L} \cdot \mathrm{min}^{-1}}^{-1300 \mathrm{~W}}$ \\
\hline $\mathrm{Pb}$ & 220.353 & Power RF & $13.0 \mathrm{~mm}$ \\
\hline $\mathrm{Se}$ & 196.026 & Plasma view & $15.0 \mathrm{~mm}$ \\
\hline $\mathrm{Zn}$ & 206.200 & View distance & - \\
\hline $\mathrm{Co}$ & 228.616 & - & \\
\hline
\end{tabular}




\section{Aqua regia extraction}

Sewage sludge samples were collected, homogenized and fraction less than $63 \mu \mathrm{m}$ obtained by sieving in a Fritsch Analysette 3 Spartan System was used for evaluation of the total content and the mobile fraction of heavy metals. The mineralization of sewage sludge samples was carried out with aqua regia $\left(\mathrm{HCl}-\mathrm{HNO}_{3} 3: 1\right) .1 \mathrm{~g}$ of dried sludge was digested in microwave oven vessels using a improved digestion program [7] for determination of the total mobile concentration [8]. Blank extraction without sewage sludge was applied for each set of analysis to control quality extraction.

\section{Leached extraction}

Extraction of metallic mobile fraction using leaching test was carried out with sludgeaqueous solution 1-10 (m/v). The samples were shaken at $40 \mathrm{rpm} \cdot \mathrm{min}^{-1}$ for 24 hours at room temperature and afterward the sewage sludge was separated from extract by centrifuge at $4000 \mathrm{rpm}$ and the metallic mobile forms were determined in the liquid [9].

\section{Results and discussion}

The total metallic content determined in four municipal sewage samples is shown in table 2. In agricultural soils can apply sludge witch the content does not exceed the limits shown in table 2. In this experiments the total content of As, was between 4.59 and $9.7 \mathrm{mg} \cdot \mathrm{kg}^{-1} \mathrm{~d} . \mathrm{m}$., which is under the maximum acceptance value $10 \mathrm{mg} \cdot \mathrm{kg}^{-1} \mathrm{~d} . \mathrm{m}$ for agricultural soil. It has been observed that the total amounts of $\mathrm{Cd}$ were situated in the range 2.08 and 9.09 and are under the limit imposed. It was reported that the $\mathrm{Cu}$ range between 93.3 and $139 \mathrm{mg} \cdot \mathrm{kg}^{-1} \mathrm{~d} . \mathrm{m}$ and is under the acceptable value. Cr and Co were below the maximum admissible limit, it was obtained that the total content of $\mathrm{Pb}$ ranged between 36.4 and $61.7 \mathrm{mg} \cdot \mathrm{kg}^{-1} \mathrm{~d}$. $\mathrm{m}$ witch are within the allowable limit, the total content of $\mathrm{Ni}$ was determined lower then imposed limit, it was detected in this study that the content of $\mathrm{Zn}$ varied between 1163 and $1680 \mathrm{mg} \cdot \mathrm{kg}^{-1} \mathrm{~d} \cdot \mathrm{m}$ which are within the acceptable value for normal agricultural soils. In all sludge samples $\mathrm{Hg}$ was under determination limit of the analytical method.

Table 2. The total metallic content in different sewage sludge samples

\begin{tabular}{|c|c|c|c|c|c|c|}
\hline $\begin{array}{l}\text { Metallic } \\
\text { elements }\end{array}$ & Unit* & $\underset{1^{* \star}}{\text { Sample }}$ & $\underset{2^{\star \star}}{\text { Sample }}$ & $\underset{3^{* *}}{\text { Sample }}$ & $\begin{array}{l}\text { Sample } \\
4^{\star *}\end{array}$ & $M A V^{* * *}$ \\
\hline As & $\mathrm{mg} \cdot \mathrm{kg}^{-1} \mathrm{~d} . \mathrm{m}$. & 9.70 & 9.10 & 4.59 & 8.51 & 10 \\
\hline $\mathrm{Cd}$ & $\mathrm{mg} \cdot \mathrm{kg}^{-1} \mathrm{~d} . \mathrm{m}$. & 7.90 & 2.08 & 3.01 & 9.09 & 10 \\
\hline $\mathrm{Cr}$ & $\mathrm{mg} \cdot \mathrm{kg}^{-1} \mathrm{~d} . \mathrm{m}$. & 484 & 93.3 & 129 & 223 & 500 \\
\hline Co & $\mathrm{mg} \cdot \mathrm{kg}^{-1} \mathrm{~d} . \mathrm{m}$. & 3.73 & 2.16 & 6.12 & 9.12 & 50 \\
\hline $\mathrm{Cu}$ & $\mathrm{mg} \cdot \mathrm{kg}^{-1} \mathrm{~d} . \mathrm{m}$. & 139 & 93.3 & 103 & 113 & 500 \\
\hline $\mathrm{Ni}$ & $\mathrm{mg} \cdot \mathrm{kg}^{-1} \mathrm{~d} . \mathrm{m}$. & 36.7 & 15 & 22.9 & 42.9 & 100 \\
\hline $\mathrm{Pb}$ & $\mathrm{mg} \cdot \mathrm{kg}^{-1} \mathrm{~d} . \mathrm{m}$. & 36.4 & 45.6 & 61.7 & 51.4 & 300 \\
\hline $\mathrm{Zn}$ & $\mathrm{mg} \cdot \mathrm{kg}^{-1} \mathrm{~d} . \mathrm{m}$. & 1507 & 1163 & 1180 & 1680 & 2000 \\
\hline $\mathrm{Hg}$ & $\mathrm{mg} \cdot \mathrm{kg}^{-1} \mathrm{~d} . \mathrm{m}$. & $<0.05^{\star \star \star \star}$ & $<0.05^{\star \star \star \star}$ & $<0.05^{\star \star \star \star}$ & $<0.05^{\star \star \star \star}$ & 5 \\
\hline
\end{tabular}

*Dry matter;

**Each result represents mean calculated of two determinations;

${ }^{* * \star}$ Maximum admissible value accepted according to Romanian Order no. 344/2004 [10];

${ }^{\star \star \star \star *}$ Results notated with < represent values situated below the determination limit. 
The concentrations of metallic mobile fraction bioavailable using leaching test in different sewage sludge samples is shown in table 3 . Leaching test is used to evaluate the mobility of heavy metals from samples and it consists in bringing into contact the sludge with leaching agent, in the report 1-10, keeping in contact $24 \mathrm{~h}$, leaching separation of extracts and analysis of obtained supernatant for determining quality indicators imposed by the current legislation. The results obtained after leaching test show tendencies of metallic elements to remain in sludge structure. All results determined for mobile As and $\mathrm{Hg}$ are below the detection limit of the method for all samples presented in table 3 .

Table 3. The metallic mobile fraction bioavailable using leaching test in different sludge samples

\begin{tabular}{|c|c|c|c|c|c|c|c|c|}
\hline \multirow{2}{*}{$\begin{array}{l}\text { Metallic } \\
\text { elements }\end{array}$} & \multirow{2}{*}{ Unit* } & \multirow{2}{*}{$\underset{1^{\star \star}}{\text { Sample }}$} & \multirow{2}{*}{$\underset{2^{* *}}{\text { Sample }}$} & \multirow{2}{*}{$\underset{3^{* \star}}{\text { Sample }}$} & \multirow{2}{*}{$\underset{4^{\star \star}}{\text { Sample }}$} & \multicolumn{3}{|c|}{$\mathrm{MAV}^{\star \star \star}$} \\
\hline & & & & & & IW & NHW & HW \\
\hline As & $\begin{array}{l}\mathrm{mg} \cdot \mathrm{kg}^{-1} \\
\text { d.m. }\end{array}$ & $<0.07$ & $<0.07$ & $<0.07$ & $<0.07$ & 0.5 & 2 & 25 \\
\hline $\mathrm{Cd}$ & $\begin{array}{l}\mathrm{mg} \cdot \mathrm{kg}^{-1} \\
\text { d.m. }\end{array}$ & 0.04 & $<0.01$ & 0.02 & 0.01 & 0.04 & 1 & 5 \\
\hline $\mathrm{Cr}$ & $\begin{array}{l}\mathrm{mg} \cdot \mathrm{kg}^{-1} \\
\text { d.m. }\end{array}$ & 0.62 & 0.8 & 0.23 & 2.44 & 0.5 & 10 & 70 \\
\hline Co & $\begin{array}{l}\mathrm{mg} \cdot \mathrm{kg}^{-1} \\
\text { d.m. }\end{array}$ & 0.13 & 0.22 & 0.16 & 0.30 & - & - & - \\
\hline $\mathrm{Cu}$ & $\begin{array}{l}\mathrm{mg} \cdot \mathrm{kg}^{-1} \\
\text { d. } \mathrm{m} .\end{array}$ & 0.93 & 1.00 & 0.68 & 1.70 & 2 & 50 & 100 \\
\hline Mo & $\begin{array}{l}\mathrm{mg} \cdot \mathrm{kg}^{-1} \\
\text { d. } \mathrm{m} .\end{array}$ & 0.17 & 0.74 & 0.03 & 0.04 & 0.5 & 10 & 30 \\
\hline $\mathrm{Ni}$ & $\begin{array}{l}\mathrm{mg} \cdot \mathrm{kg}^{-1} \\
\text { d.m. }\end{array}$ & 0.16 & 2.57 & 0.33 & 2.90 & 0.4 & 10 & 40 \\
\hline $\mathrm{Pb}$ & $\begin{array}{l}\mathrm{mg} \cdot \mathrm{kg}^{-1} \\
\text { d.m. }\end{array}$ & $<0.05$ & 0.11 & 0.05 & 1.10 & 0.5 & 10 & 50 \\
\hline $\mathrm{Se}$ & $\begin{array}{l}\mathrm{mg} \cdot \mathrm{kg}^{-1} \\
\text { d. } \mathrm{m} .\end{array}$ & 0.06 & $<0.04$ & 0.11 & 0.08 & 0.1 & 0.5 & 7 \\
\hline $\mathrm{Zn}$ & $\begin{array}{l}\mathrm{mg} \cdot \mathrm{kg}^{-1} \\
\text { d.m. }\end{array}$ & 2.48 & 2.89 & 7.62 & 50 & 4 & 50 & 200 \\
\hline $\mathrm{Hg}$ & $\begin{array}{l}\mathrm{mg} \cdot \mathrm{kg}^{-1} \\
\text { d.m. }\end{array}$ & $<0.0001^{* * * *}$ & $<0.0001^{* * * *}$ & $<0.0001^{* * \star *}$ & $<0.0001^{* * * *}$ & 0.01 & 0.2 & 2 \\
\hline
\end{tabular}

*Dry matter;

${ }^{* *}$ Each result represents mean calculated of two determinations;

${ }^{* * *}$ Maximum admissible value accepted according to Romanian Order no. 95/2005 [11], IW- inert waste, NHW - non- hazardous waste, HW- hazardous waste;

${ }^{* * * *}$ Results notated with < represent values situated below the determination limit.

For mobile $\mathrm{Cd}, \mathrm{Pb}$ and $\mathrm{Se}$ were obtained values below the detection limit or very close to this limit. The water soluble $\mathrm{Cu}$ in all cases was below the maximum admissible value for non-hazardous waste. Due to low solubility, only a little amount of $\mathrm{Cr}$ is soluble in water for samples 1-3 and more soluble in water for sample 4.

The analysis of $\mathrm{Co}, \mathrm{Mo}, \mathrm{Ni}$, Se and $\mathrm{Zn}$ metals, show that the concentrations studied does not exceed maximum admissible value according to Romanian Order no. 95/2005 [11] for non-hazardous waste. Experimental results obtained demonstrates 
that the metals detected in this study are weak available and do not present the negative impact on environmental pollution and human health.

\section{Mobility of heavy metals}

The mobility and immobility of heavy metals along with their bioavailability from sludge in soil is largely depending on their binding form. The percent of mobile heavy metals obtained by leaching extraction method are presented in Fig. 1. In this study was determined the mobile form soluble in water, which is relevant to evaluate the risk of contamination of the soil, groundwater and surface water. Mobility of heavy metals decreased in order and could be given as $\mathrm{Co}(3.5 \%)>\mathrm{Cu}(0.7 \%)>\mathrm{Cd}(0.5 \%)>\mathrm{Ni}$ $(0.4 \%)>\operatorname{Zn}(0.16 \%)>\operatorname{Cr}(0.1 \%)$ for sample 1 , Co $(6.0 \%)>\operatorname{Cd}(1.9 \%)>\mathrm{Ni}(1.1 \%)>$ $\mathrm{Cu}(1.0 \%)>\mathrm{Cr}(0.7 \%)>\mathrm{Zn}(0.2 \%)$ for sample 2 , Co $(2.6 \%)>\mathrm{Ni}(1.4 \%)>\mathrm{Cd}$ and $\mathrm{Cu}$ $(0.7 \%)>\operatorname{Zn}(0.6 \%)>\operatorname{Cr}(0.2 \%)>\mathrm{Pb}(0.1 \%)$ for sample 3 and for sample $4, \mathrm{Ni}(6.8 \%)$ $>\mathrm{Co}(3.3 \%)>\mathrm{Zn}(3.0 \%)>\mathrm{Pb}(2.1 \%)>\mathrm{Cu}(1.5 \%)>\mathrm{Cr}(1.1 \%)>\mathrm{Cd}(0.1 \%)$. For Mo, $\mathrm{Se}$ and $\mathrm{Hg}$ mobility forms were not detected in all samples. Therefore, evaluation of mobile fraction can provide very important information for management of sludge in agricultural fields or other destinations.

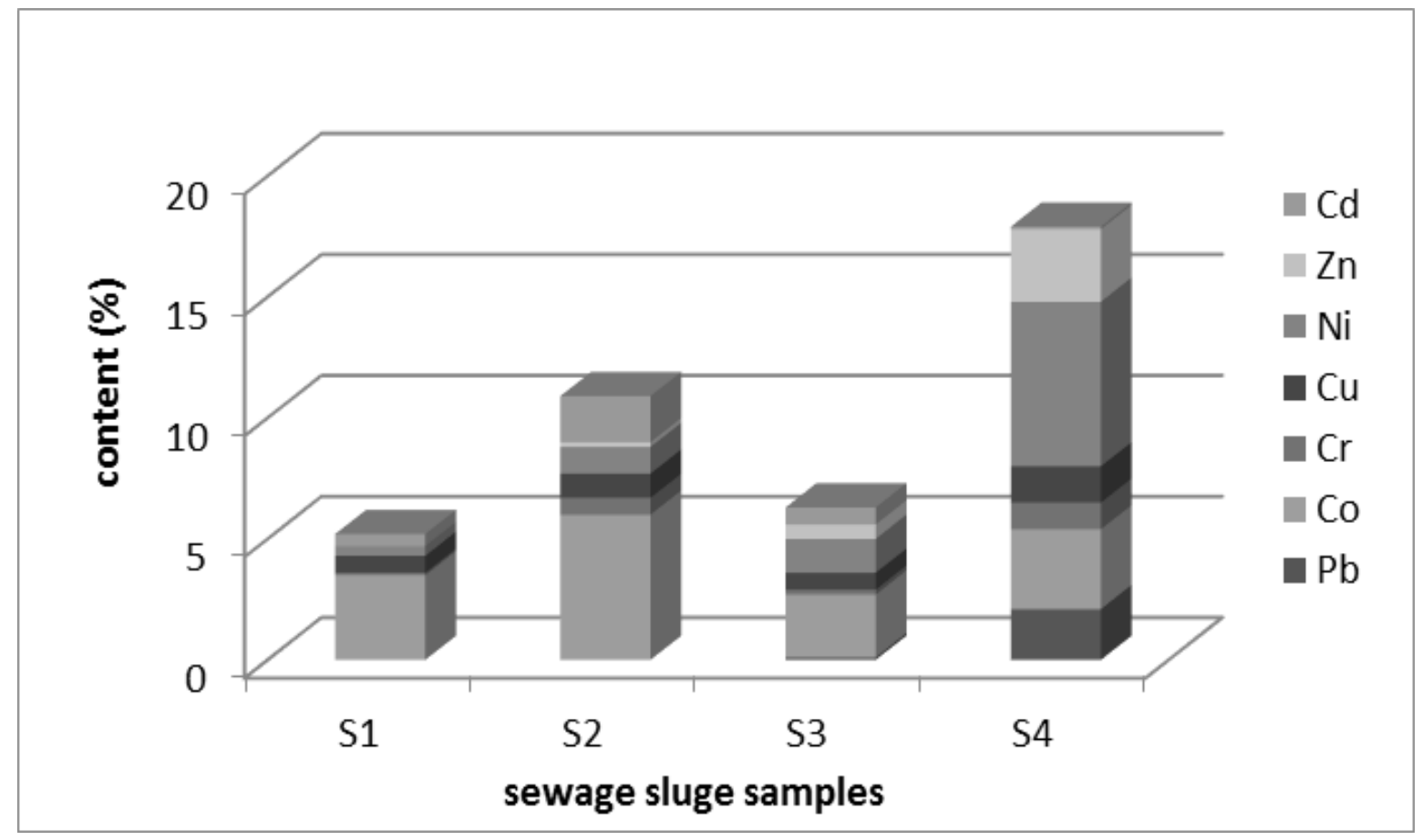

Fig. 1 Mobility content of heavy metals in sewage sludge samples

In table 4 are presented immobile content of heavy metals from sewage sludge samples. The sewage sludge samples were characterized by the highest immobile content of $\mathrm{Cd}$, Co, Cr, Cu, Ni, $\mathrm{Pb}$ and $\mathrm{Zn}$ that range between $96.5 \%$ and $100 \%$ (table 4). Based on these results, can be concluded that the dominant form of heavy metals in sewage sludge are immobile. 
Table 4. Immobility content of heavy metals in different sludge samples

\begin{tabular}{|c|c|c|c|c|c|}
\hline $\begin{array}{c}\text { Metallic } \\
\text { elements }\end{array}$ & Unit & $\begin{array}{c}\text { Sample } \\
\mathbf{1}\end{array}$ & $\begin{array}{c}\text { Sample } \\
\mathbf{2}\end{array}$ & $\begin{array}{c}\text { Sample } \\
\mathbf{3}\end{array}$ & $\begin{array}{c}\text { Sample } \\
\mathbf{4}\end{array}$ \\
\hline $\mathrm{Cd}$ & $\%$ & 99.5 & 98.1 & 99.3 & 99.9 \\
\hline $\mathrm{Cr}$ & $\%$ & 99.9 & 99.3 & 99.8 & 98.9 \\
\hline $\mathrm{Co}$ & $\%$ & 96.5 & 94.0 & 97.4 & 96.7 \\
\hline $\mathrm{Cu}$ & $\%$ & 99.3 & 99.0 & 99.3 & 98.5 \\
\hline $\mathrm{Ni}$ & $\%$ & 99.6 & 98.9 & 98.6 & 93.2 \\
\hline $\mathrm{Pb}$ & $\%$ & 100.0 & 100.0 & 99.9 & 97.9 \\
\hline $\mathrm{Zn}$ & $\%$ & 99.8 & 99.8 & 99.4 & 97.0 \\
\hline
\end{tabular}

\section{Conclusions}

In this paper the experimental data show that the results detected for all heavy metals studied are included bellow the maximum admissible value according to Romanian Order no. 344/2004 and do not provide environmental risk.

Metallic mobile fractions were detected from different sewage sludge samples using leaching test. Results determined of leachable fractions were compared with the imposed values of these elements in sludge.

The low levels of heavy metals accumulated in all sewage sludge samples allow its use as for degraded soils, fertilizer in agriculture or to be storage as a non-hazardous waste.

\section{Acknowledgements}

The authors are grateful for the financial support of project PN $16250109-2016$ (Contract no. 38N/2016).

\section{References}

[1] B.R. Sabey, "The use of sewage sludge as a fertilizer". Handbook of organic waste conversion, (1980).

[2] Directive 86/278/EEC, Council directive on the protection of the environment, and in particular of the soil, when sewage sludge is used in agriculture. Official Journal of the European Communities, 1986.

[3] G. Jarosław, G. Barbara, "Mobility of Heavy Metals in Municipal Sewage Sludge from Different Throughput Sewage Treatment Plants", Polish Journal of Environmental. Studies, 2012, 21(6), 1603-1611.

[4] A. Sungur, M. Soylak, H. Ozcan, "Investigation of heavy metal mobility and availability by the BCR sequential extraction procedure: relationship between soil properties and heavy metals availability", Chemical Speciation \& Bioavability, 2014, 26(4), 219-230.

[5] SR EN ISO 11885:2009 Water quality. Determination of selected elements by inductively coupled plasma optical emission spectrometry (ICP-OES).

[6] SR EN ISO 17852:2008 Water quality. Determination of mercury. Method using a combined preservation and digestion step followed by atomic fluorescence spectrometry. 
[7] N.M. Marin, G.G. Vasile, J. Petre, L.V. Cruceru, "Improved aqua regia metal extraction using a loam soil CRM ERC-CC141 and a performant microwave oven", Proceedings Volume, ISSN 2457-8371, 2015, 215-219.

[8] SR EN 16174/2013 Sludge, treated bio waste and soil - Digestion of aqua regia soluble fractions of elements.

[9] SR EN 12457-2:2003 Characterization of waste - Leaching; Compliance test for leaching of granular waste materials and sludges - Part 2: One-stage batch test at a liquid to solids ratio of $10 \mathrm{l} / \mathrm{kg}$ for materials with a particle size below $4 \mathrm{~mm}$ (with or without size reduction). [10] Romanian Order no. 344/2004 regarding Technical rules on environmental and in particular, soils when are used amended sewage sludge in agriculture.

[11] Order 95/2005 establishing acceptance criteria and preliminary procedures for acceptances of waste storage and national list of waste accepted in each class of landfill. 